\title{
ANEKA PERMASALAHAN MENGENAI PERJANJIAN KAWIN PENGESAHAN ATAU PENCATATAN
}

Oleh:

\section{Sylvia Widjaja}

\begin{abstract}
To make a prenuptial agreement is still considered as taboo by Indonesian couple, although there has been awareness to make such prenuptial agreement for transnational couple. Marriage in Indonesia is regulated under Law No. 1 of 1974 on Marriage ("Marriage Law"). The prenuptial agreement is a term taken from the heading of the $5^{\text {th }}$ Chapter of Marriage Law, which consist of only one article, i.e. article 29 paragraph 1, 2, 3 and 4, that only regulates the period of when the prenuptial agreement shall be made, it's legality, the time of when it will enter into force and the possibility to amend such agreement. In other words, Marriage Law does not describe the definition of prenuptial agreement, and also does not determine matters that can be agreed upon, which priorly regulated under the Indonesian Civil Code. In relation to the prenuptial agreement under the Marriage Law, there occur several legal questions, among others: First, Does the registration officer from the Civil Registration Office will only make registration of the prenuptial agreement or will he/she also legalizing it?. Second, Does the prenuptial agreement only regulate assets which originated from the grant and inheritance? And Last, Why the prenuptial agreement may only be made prior to the marriage, meanwhile the Marriage Law allows the amendment of the prenuptial agreement?. This research analyzes and discusses, and will provide answers or views to the above questions, which hopefully could be helpful and give insight for all readers.
\end{abstract}

\section{Keywords: Prenuptial Agreement, Civil Registration Office, Marriage Law.}

\section{PENDAHULUAN}

Perkawinan di Indonesia diatur dalam Undang-Undang No 1/Tahun 1974 tentang Perkawinan (disingkat UUP). Istilah perjanjian kawin merupakan istilah yang diambil dari judul Bab V UU No.1 th 1974 (UUP) yang hanya berisi satu pasal, yaitu pasal 29 yang terdiri dari ayat (1), (2), (3), dan (4), dimana pengertian tentang perjanjian perkawinan tidak diperoleh penjelasannya, hanya mengatur antara lain tentang kapan perjanjian kawin itu dibuat, keabsahannya, saat berlakunya dan dapat diubahnya perjanjian itu. Jadi sama sekali tidak mengatur tentang materi perjanjian seperti yang diatur dalam Kitab UndangUndang Hukum Perdata Indonesia (KUHPerdata).

Perjanjian perkawinan merupakan perjanjian yang dibuat oleh calon pasangan pengantin sebelum perkawinan dilangsungkan, dimana isi perjanjian yang dibuat mengikat hubungan perkawinan 
diantara pasangan tersebut ${ }^{1}$. Secara umum, perjanjian perkawinan berisi tentang pengaturan harta kekayaan calon suami-isteri. Tujuan dari pembuatan perjanjian perkawinan umumnya adalah untuk mengatur akibat akibat perkawinan yang menyangkut harta kekayaan.

Sebelum diundangkannya UU No.1 Tahun 1974 tentang Perkawinan, (selanjutnya dalam tulisan ini akan disebut UUP), menurut pasal 147 KUHPerdata: "Atas ancaman kebatalan, setiap perjanjian perkawinan harus dibuat dengan akta notaris sebelum perkawinan berlangsung. Perjanjian mulai berlaku semenjak saat perkawinan dilangsungkan, lain saat untuk itu tak boleh ditetaperjanjian kawinannya." (Perjanjian perkawinan dalam tulisan ini selanjutnya ditulis dengan Perjanjian Kawin).

Selanjutnya menurut pasal 152 KUHPerdata disebutkan: "Ketentuanketentuan yang tercantum dalam Perjanjain Kawin yang mengandung penyimpangan dari persatuan menurut undang-undang seluruhnya atau untuk sebagian, tak akan berlaku terhadap pihak ketiga, sebelum hari ketentuan-ketentuan itu dibukukan dalam suatu register umum, yang harus diselenggarakan untuk itu di kepaniteraan pada Pengadilan Negeri, yang mana dalam daerah hukumnya perkawinan itu telah dilangsungkan, atau jika perkawinan berlangsung di luar negeri, di kepaniteraan dimana akta perkawinan dibukukannya“"

Setelah diundangkannya UUP, dalam pasal 29 ayat (1) UUP disebutkan: "sebelum atau pada waktu perkawinan dilangsungkan, kedua pihak atas perjanjian bersama dapat mengadakan perjanjian tertulis yang disahkan oleh Pegawai Pencatat Perkawinan, setelah

1 Happy Susanto, Pembagian Harta Gono Gini Saat Terjadinya Perceraian, Jakarta: Visimedia, 2008, hlm.78. mana isinya berlaku juga terhadap pihak ketiga sepanjang pihak ketiga tersangkut ".

Adapun pasal 29 ayat (2) UUP menyebutkan: "Perjanjian Kawin" tidak dapat disahkan bilamana melanggar batas batas hukum, agama dan kesusilaan, sedangkan Pasal 29 ayat (3) UUP mengatur bahwa Perjanjian Kawin berlaku sejak perkawinan dilangsungkan.

Redaksi pasal 29 ayat (1), ayat (2), dan ayat (3) UUP tersebut dalam praktik menimbulkan beberapa pertanyaan sebagai berikut:

1) Apakah kata "disahkan" dalam ayat (1) pasal 29 mempunyai makna yang sama dengan kata "dibukukan" ex Pasal 147 KUHPerdata ? dan Apakah Pegawai Pencatat Perkawinan "mengesahkan" atau "membukukan (mencatat)" Perjanjian Kawin ?;

2) Apakah Pasal 29 ayat (1) dan (2) UUP kini telah berlaku?;

3) Kapan mulai berlakunya Perjanjian Kawin terhadap suami-isteri yang membuatnya dan terhadap pihak ketiga tersangkut?

Sehubungan dengan beberapa pertanyaan tersebut di atas, dalam pembahasan ini akan diuraikan antara lain:

\section{MENGESAHKAN DAN ATAU MEMBUKUKAN (MENCATATKAN)}

Dari redaksi pasal 29 ayat (1) UUP yang berbunyi : "yang disahkan oleh Pegawai Pencatat Perkawinan", jelas bahwa yang harus dilakukan oleh Pegawai Pencatat Perkawinan terhadap Perjanjian Kawin adalah "pengesahan", apalagi kalau kita kaitkan dengan redaksi ayat (3) UUP yang berbunyi: "Perjanjian Kawin tidak dapat disahkan bilamana melanggar batas-batas hukum, agama dan kesusilaan." 
APAKAH PENGESAHAN EX PASAL 29 AYAT (1) UUP MEMPUNYAI MAKNA YANG SAMA DENGAN PEMBUKUAN (PENCATATAN) EX PASAL 152 KUHPERDATA?

Secara harafiah pengertian hukum dari kata "mencatat" atau "membukukan" dalam arti "overschrijven", seperti yang dimaksud dalam pasal 152 KUHPerdata Indonesia sebagai syarat bagi berlakunya Perjanjian Kawin terhadap pihak ketiga, adalah berbeda maknanya dengan pengertian hukum dari kata "mengesahkan" yang berarti "bewilligen" seperti yang dimuat dalam pasal 36 KUHDagang (Wetboek van Koophandel) Indonesia mengenai pengesahan perseroan terbatas sebagai badan Hukum.

\section{PENDAPAT BAHWA PENGESAHAN EX PASAL 29 AYAT (1) UUP HARUS DIBACA SEBAGAI PEMBUKUAN (PENCATATAN) PERJANJIAN KAWIN}

Herlien Budiono, berpendapat bahwa dalam kenyataannya pengesahan Perjanjian Kawin oleh Pegawai Pencatat Perkawinan, tidak lebih dari pembukuan (overschrijving). Perjanjian Kawin dalam suatu daftar umum (openbaar register), dan bahwa kata-kata "setelah mana isinya berlaku juga terhadap pihak ketiga, sepanjang pihak ketiga tersangkut"pada pasal 29 ayat (1) UUP, menunjukan bahwa pengesahan tersebut hanya disyaratkan bagi berlakunya Perjanjian Kawin terhadap pihak ketiga yang tersangkut dan bukan disyaratkan bagi berlakunya Perjanjian Kawin terhadap suami-isteri yang membuatnya. ${ }^{2}$ Adapun belum disahkan, dibukukan/didaftarkannya akta Perjanjian Kawin tersebut di atas oleh Pegawai Pencatat Perkawinan hingga saat perkawinan

${ }^{2}$ Herlien Budiono, Kumpulan Tulisan Hukum Perdata di Bidang Kenotariatan, Buku Kedua, Bandung: Citra Aditya Bakti, 2010, hlm 1-16. dilangsungkan, tidak mengurangi keabsahan dan berlakunya Perjanjian Kawin tersebut terhadap suami-isteri yang bersangkutan oleh karena pengesahan/pembukuan/pendaftaran Perjanjian Kawin oleh Pegawai Pencatat Perkawinan menurut Pasal 29 ayat (1) UUP hanya disyaratkan bagi berlakunya Perjanjian Kawin tersebut terhadap pihak ketiga terkait. ${ }^{3}$ Jadi menurut Herlien Budiono, makna dari kata "pengesahan" ex. Pasal 29 ayat (1) UUP adalah sama seperti halnya dengan makna pasal 52 KUHPerdata.

Terlepas dari perbedaan pengertian hukum antara istilah hukum "pembukuan (pencatatan) dalam arti "overschrijving", dan "pengesahan" dalam arti "bewilliging" tersebut diatas, pendapat Herlien Budiono tersebut dapat kita pahami karena memang pada kenyataannya yang dilakukan oleh Pegawai Pencatat Perkawinan hingga saat ini bukanlah mengesahkan melainkan hanya membukukan (mencatat) Perjanjian Kawin, karena kata "disahkan" ex pasal 29 ayat (1) UUP hingga kini belum ada peraturan pelaksanaannya, sebagaimana akan diuraikan lebih lanjut dibawah ini.

PENGESAHAN EX PASAL 29 AYAT (1) UUP BELUM DAPAT DILAKSANAKAN KARENA BELUM ADA PERATURAN PELAKSANAANNYA

Pengesahan ex. pasal 29 ayat (1) UUP belum berlaku karena semua peraturan perundang-undangan yang terbit setelah UUP hanya mengatur mengenai "pencatatan" dan bukan "pengesahan", sehingga syarat "pengesahan" ex pasal 29 ayat (1) UUP belum berlaku karena belum ada peraturan pelaksanaannya.

Meskipun UUP dalam Pasal 29 ayat (1) dan (2) menyebutkan mengenai "pengesahan" Perjanjian Kawin , namun "pengesahan" ex.

\footnotetext{
${ }^{3}$ Ibid.
} 
pasal 29 ayat (1) dan (2) UUP, harus dianggap belum berlaku, karena belum ada peraturan pelaksanaannya, mengingat UU, Peraturan Presiden, dan Peraturan Daerah yang ada hingga saat ini semuanya mengatur bahwa Pencatatan Sipil bukan mengesahkan melainkan mencatat/membukukan Perjanjian Kawin, hal mana ternyata dari:

a) Undang-undang No. 23 Tahun 2006 Pasal 1 angka 15 yang berbunyi: "Pencatatan Sipil adalah pencatatan peristiwa penting yang dialami oleh seseorang dalam register Pencatatan Sipil pada instansi Pelaksana";

b) Peraturan Presiden Republik Indonesia No. 25 Tahun 2008 tanggal 4 April 2008 tentang Persyaratan Dan Tata Cara Pendaftaran Penduduk Dan Pencatatan Sipil Bab I Ketentuan Umum, yang berbunyi:

i. Pasal 1 angka 14: "Pencatatan Sipil adalah pencatatan peristiwa penting yang dialami seseorang dalam register Pencatatan Sipil pada instansi pelaksana";

ii. Pasal 1 angka 15 yang berbunyi: "Pejabat Pencatatan Sipil adalah Pejabat yang melakukan pencatatan peristiwa penting yang dialami seseorang pada Instansi Pelaksana yang pengangkatannya sesuai dengan Peraturan Perundangundangan";

c) Peraturan Daerah Kota Bandung No. 07 Tahun 2009 tentang Penyelenggaraan Administrasi Kependudukan,dan Peraturan Daerah Kota Bandung No.29 Tahun 2009 tentang Retribusi Pelayanan Administrasi Kependudukan,yang menurut Dinas Kependudukan Dan Pencatatan Sipil Kota Bandung merupakan peraturan pelaksanaan dari ketentuan pasal 29 ayat (1) UndangUndang No.1 Tahun 1974 tentang perkawinan ( vide surat Kepala Dinas Kependudukan Dan Pencatatan Sipil Kota Bandung tertanggal 8 Desember 2011 No. 470/1913- Disdukcapil yang dalam:

(i) Angka 2-nya menyebutkan bahwa: "Bahwa terhadap Perjanjian Perkawinan yang dilaporkan oleh pemohon maka Dinas Kependudukan Dan Pencatatan Sipil Kota Bandung dahulu Kantor Catatan Sipil mencatat dalam Register Perkawinan pemohon dan didaftarkan di Register Perjanjian Perkawinan serta diterbitkan catatan pinggir"; dan

(ii) Angka 3-nya menyebutkan bahwa: "sebagai bukti bahwa Perjanjian Perkawinan telah dicatatkan, maka diterbitkan catatan pinggir yang berisi keterangan tentang pencatatan Perjanjian Perkawinan dimaksud");

Dari redaksi peraturan peraturan perundang-undangan tersebut di atas, ternyata bahwa apa yang hingga kini dilakukan Catatan Sipil berkenaan dengan Perjanjian Kawin adalah hanya mencatat (membukukan) dan bukan mengesahkan.

Apabila kita teliti ketentuan pasal 1 angka 17 undang-undang No. 23 Tahun 2006 dan Pasal 1 angka16 Peraturan Presiden Republik Indonesia No. 25 Tahun 2008 yang keduanya berbunyi:

"Peristiwa penting adalah kejadian yang dialami oleh seseorang meliputi kelahiran, kematian, lahir mati, perkawinan, perceraian, pengakuan anak, pengesahan anak, pengangkatan anak, perubahan nama dan perubahan status kewarganegaraan", maka nampak jelas bahwa dalam peristiwa penting yang dialami seseorang yang dicatat oleh 
Catatan Sipil tidak disebutkan secara eksplisit mengenai Perjanjian Kawin.

\section{BERLAKUNYA ISI PERJANJIAN KAWIN TERHADAP SUAMI-ISTERI DAN TERHADAP PIHAK KETIGA TERSANGKUT}

Apabila kita hanya melihat redaksi Pasal 29 UUP, maka dari kata-kata: "setelah mana isinya berlaku juga terhadap pihak ketiga sepanjang pihak ketiga tersangkut", pada pasal 29 ayat (1) UUP, orang mungkin berpendapat bahwa pengesahan oleh Pegawai Pencatat Perkawinan merupakan syarat bagi berlakunya isi Perjanjian Kawin baik terhadap suami isteri yang membuatnya maupun terhadap pihak ketiga tersangkut.

Demikian pula dari redaksi ayat (2) UUP yang berbunyi : "Perjanjian tersebut tidak dapat disahkan bilamana melanggar batas batas hukum, agama dan kesusilaan", nampak bahwa Pegawai Pencatat Perkawinan bukan sekedar mencatat, melainkan benar benar "mengesahkan" Perjanjian Kawin. Untuk itu Pegawai Pencatat Perkawinan berwenang untuk menolak pengesahan Perjanjian Kawin yang isinya melanggar batas batas hukum, agama dan kesusilaan.

Sehubungan dengan penolakan pengesahan Perjanjian Kawin tersebut, jelas bahwa "pengesahan" bukan hanya disyaratkan bagi berlakunya isi Perjanjian Kawin terhadap pihak ketiga tersangkut, akan tetapi juga bagi berlakunya isi Perjanjian Kawin terhadap suami isteri, karena isi Perjanjian Kawin yang bertentangan dengan batas-batas hukum, agama dan kesusilaan, tentu saja tidak mungkin dinyatakan tidak berlaku bagi pihak ketiga tersangkut, tetapi dinyatakan berlaku bagi suami-isteri yang bersangkutan, hal mana terlihat jelas dari dicantumkannya kata "juga" pada redaksi ayat (1) Pasal 29 UUP yang berbunyi: "setelah mana isinya berlaku juga terhadap pihak ketiga sepanjang pihak ketiga tersangkut".

Ketentuan pasal 29 ayat (3) UUP yang menyebutkan bahwa: "perjanjian tersebut berlaku sejak perkawinan dilangsungkan", tanpa membedakan saat berlakunya Perjanjian Kawin terhadap pasangan suami isteri dan terhadap pihak ketiga tersangkut, juga menunjukkan bahwa pengesahan tersebut bukan saja disyaratkan bagi berlakunya Perjanjian Kawin tersebut terhadap kedua mempelai akan tetapi juga bagi pihak ketiga, karena bagi kedua-duanya Perjanjian Kawin sudah harus berlaku sejak saat perkawinan dilangsungkan. UUP tidak menetaperjanjian kawinan ketentuan seperti yang tercantum dalam Pasal 152 UUP yang mengatur "pembukuan"(pencatatan) Perjanjian Kawin sebagai syarat berlakunya Perjanjian Kawin terhadap pihak ketiga.

Jadi kata "disahkan" pada pasal 29 ayat (1) UUP mempunyai makna yang sama sekali berbeda dengan makna kata "dibukukan" (dicatat) pada pasal 152 KUHPerdata.

Apa makna sebetulnya dari redaksi Pasal 29 ayat (2) UUP tersebut, karena bukankah perjanjian yang bertentangan dengan hukum yang bersifat memaksa, agama dan kesusilaan, demi hukum (dengan sendirinya) batal.

\section{TETAP BERLAKUNYA KETENTUAN LAMA}

Namun sebagaimana telah diuraikan tersebut di atas, mengenai "pengesahan" ex Pasal 29 UUP hingga kini belum dapat dilaksanakan karena belum ada peraturan pelaksanaannya, sehingga untuk berlakunya Perjanjian Kawin terhadap suami-isteri yang membuatnya masih diberlakukan ketentuan lama ex. Pasal 147 ayat (2) KUHPerdata, dan ketentuan mengenai "pembukuan" (pencatatan) ex. pasal-pasal 152 KUHPerdata untuk berlakunya Perjanjian Kawin terhadap pihak ketiga tersangkut. 
Mensyaratkan "pengesahan" bagi Perjanjian Kawin yang dibuat suami-isteri setelah diundangkannya UUP hingga kini adalah tidak mungkin, karena berdasarkan peraturan perundang-undangan yang disebutkan tersebut diatas, Pencatatan Sipil di seluruh Indonesia sejak berlakunya UUP, tidak pernah "mengesahkan", melainkan hanya "mencatat" (membukukan) Perjanjian Kawin, sehingga apabila "pengesahan" disyaratkan bagi sahnya suatu Perjanjian Kawin, maka hal itu akan berakibat sangat tragis dan tidak masuk akal sama sekali, yaitu tidak sahnya semua Perjanjian Kawin yang dibuat setelah berlakunya UUP, bukan hanya terhadap suami-isteri akan tetapi juga terhadap pihak ketiga terkait ,karena berdasarkan peraturan perundang-undangan (peraturan pelaksanaan) yang berlaku, hingga saat ini Perjanjian Kawin hanya "dicatat (dibukukan)" dan bukan disahkan oleh Pencatatan Sipil di seluruh Indonesia.

Sehubungan dengan tidak lagi dimuatnya keharusan pembuatan dengan akta otentik notariil, syarat pengesahan Perjanjian Kawin mungkin oleh pembuat UUP dimaksudkan guna mencegah praktik pembuatan secara di bawah tangan dengan tanggal mundur, sehingga keharusan membuat Perjanjian Kawin sebelum atau pada saat dilangsungkannya perkawinan sebagaimana ditetapkan dalama perjanjian kawin dalam ayat (1) pasal 29 UUP dengan mudah dapat diselundupi.

Fungsi "pencatatan" dalam register umum adalah untuk memenuhi azas "publisitas" yaitu agar adanya Perjanjian Kawin diketahui oleh pihak ketiga sehingga dapat diberlakukan terhadap pihak ketiga terkait.

Fungsi "publisitas" dari "pencatatan" tidak mungkin disyaratkan bagi berlakunya Perjanjian Kawin terhadap suami-isteri yang membuatnya, karena dengan membuat dan menandatangani sendiri Perjanjian Kawin tersebut mereka pasti telah mengetahui adanya Perjanjian yang dibuatnya sehingga menurut pasal 1338 Kitab Undang-Undang Hukum Perdata (Burgerlijk Wetboek) Indonesia mengikat sebagai undang-undang bagi pasangan suami-isteri yang membuatnya, serta harus dilaksanakan dengan itikad baik;

Bandingkan dengan ketentuan pasal 152 Kitab Undang Undang Hukum Perdata (Burgerlijk Wetboek) Indonesia yang hanya mensyaratkan pencatatan (pembukuan) bagi berlakunya Perjanjian Kawin bagi pihak ketiga, sedangkan untuk berlakunya Perjanjian Perkawinan bagi pasangan suamiisteri yang membuat Perjanjian Kawin, cukup disyaratkan bahwa perkawinan telah berlangsung, sehingga tidak disyaratkan pencatatan (pembukuan) Perjanjian Kawin.

Mengenai hal ini Ko Tjay Sing berkomentar sebagai berikut: "Apabila perdjandjian kawin sama sekali tidak diturun dalam register tersebut atau hanya sebagian dari ketentuan-ketentuan yang telah diturun, maka pada umumnya (lihatlah kekecualian di bawah ini) seluruh perdjanjian kawin, atau ketentuan-ketentuan yang tidak diturun tidaklah berlaku bagi pihak ketiga. Ini adalah logis karena fihak ketiga yang memeriksa register umum tersebut tidak dapat mengetahuinja". "Apabila suami dan isteri tidak menghendaki, bahwa perdjandjian kawin akan berlaku bagi fihak ketiga, maka seluruh perdjandjian kawin tidak harus diturun dalam register tersebut. Djika mereka menghendaki, agar hanja beberapa ketentuan ketentuan dari perdjanjian berlaku terhadap fihak ketiga, maka hanja ketentuan-ketentuan itu jang harus diturun dalam register tersebut. Terserah kepada suami-isteri apa yang mereka hendak membukukan, mereka tidak berwajib

4 Ko Tjay Sing, Hukum Perdata Jilid I, Hukum Keluarga (Diktat Lengkap), Semarang: Etikad Baik, 1981, hlm. 251-252. 
mengadakan pembukuan tersebut, asal mereka bersedia memikul akibat-akibatnja". 5

"Di atas dikatakan bahwa ketentuanketentuan dalam perdjanjian kawin jang tidak diturun dalam register umum, tidak berlaku bagi fihak ketiga. Ini berarti bahwan suami dan/atau isteri tidak boleh menggunakan ketentuan-ketentuan itu terhadap fihak ketiga, tetapi sebaliknja fihak ketiga jang kemudian (j.i, setelah mereka mengadakan hubungan hukum dengan suami dan/atau isteri) mengetahui adanja perdjandjian kawin dan isinja, boleh menggunakan ketentuanketentuan itu terhadap suami dan/atau isteri, seolah-olah ketentuan-ketentuan tersebut telah diumumkan dalam register tersebut". (Hoge Raad tgl18 -2-1916 N.J. 1916, hal. 513, W.P.N.R 2464).

"Djadi fihak ketiga boleh menganggap, bahwa ketentuan-ketentuan jang tidak diumumkan tadi sebagai ada atau tidak ada. Pada umumnja ketentuan-ketentuan perdjanjian kawin jang tidak diumumkan, dengan demikian dapat menguntungkan, tetapi tidak merugikan fihak ketiga". "Akan tetapi bila suami atau isteri bisa membuktikan, bahwa ketentuan-ketentuan jang tidak diumumkan tadi, diketahui oleh fihak ketiga sebelum atau pada saat mereka mengadakan hubungan hukum dengan suami dan/atau isteri, maka ketentuan-ketentuan itu berlaku terhadap fihak ketiga jang mengetahuinja". 6

Mengenai persoalan apakah pihak ketiga terikat pada tiap-tiap ketentuan dalam Perjanjian Kawin yang didaftarkan, A. Pitlo berpendapat bahwa undang-undang yang menentukan kewajiban pendaftaran itu. Kewajiban pendaftaran itu adalah untuk melindungi kepentingan pihak ketiga, bukan untuk memberikan kesempatan kepada suami isteri untuk mengikat pihak ketiga dengan

\footnotetext{
${ }^{5}$ Ibid.

${ }^{6}$ Ibid.
}

sesuatu yang tidak benar ${ }^{7}$ Dengan berpangkal kepada hal tersebut diatas A. Pitlo berpendirian bahwa akibat-akibat Perjanjian Kawin terhadap pihak ketiga harus kita bedakan menurut sifat ketentuanketentuan yang dimuat dalam Perjanjian Kawin itu sendiri.

Sekiranya ada ketentuan-ketentuan dalam akibat Perjanjian Kawin yang bersifat materieel-rechtelijk, artinya dengan ketentuan dalam Perjanjian Kawin timbul suatu keadaan harta kekayaan tertentu; misalnya suami-isteri kawin dengan persatuan yang terbatas atau sama sekali tidak ada persatuan harta kekayaan, maka terhadap hal ini pihak ketiga sepenuhnya sejak saat pendaftaran Perjanjian Kawin itu.

Akan tetapi ada ketentuan-ketentuan dalam Perjanjian Kawin bersifat lain yakni yang mengenai pernyataan suami isteri mengenai pembuktian barang barang asal mereka masing masing. Dalam hal ini adalah mungkin saja apa yang dinyatakan dalam Perjanjian Kawin itu berlainan dengan hal yang sebenarnya. Yang menjadi persoalan, apakah dalam hal yang demikian itu pihak ketiga - sesudah pendaftaran itu - terikat juga kepada pernyataan suami-isteri itu, ataukah pihak ketiga dapat mengabaikan pernyataan suami-isteri yang demikian itu?

Menurut A. Pitlo, dalam hal yang demikian, hakimlah yang menentukan sampai sejauh mana pihak ketiga terikat pada pernyataan suami isteri itu. Seperti pada tiaptiap akta, maka akta Perjanjian Kawin mempunyai kekuatan pembuktian bebas (vrije bewijskracht) terhadap pihak ketiga. ${ }^{8}$ Sesuai dengan ketentuan Pasal 29 ayat (3) UU No.1 Tahun 1974, seperti halnya Pasal 147 Kitab Undang-Undang Hukum Perdata

7 R. Soetojo Prawirohamidjojo dan Asis Safioedin, Hukum Orang Dan Keluarga, cetakan kelima, Bandung: Alumni, 1986, hlm.84-85.

${ }^{8}$ Ibid. 
Indonesia, terhadap suami-isteri, tanpa disyaratkan keharusan pendaftaran/pencatatan/ pembukuan terlebih dahulu, Perjanjian Kawin harus dianggap telah berlaku sejak dilangsungkannya perkawinan mereka .

\section{TIDAK ADA LAGI PERSYARATAN BENTUK OTENTIK NOTARIIL BAGI PERJANJIAN KAWIN}

Pasal 29 ayat (1) hanya mensyaratkan agar Perjanjian Kawin dibuat secara tertulis, tidak seperti B.W. (KUHPerdata) yang mensyaratkan bahwa Perjanjian Kawin harus dibuat secara otentik notariil.

Tidak disyaratkannya pembuatan Perjanjian Kawin secara notariil (otentik) dalam Pasal 29 ayat (1) UUP, membuka peluang bagi terjadinya pelanggaran terhadap keharusan pembuatan Perjanjian Kawin sebelum atau pada waktu dilangsungkannya perkawinan, dengan cara pembuatan Perjanjian Kawin secara di bawah tangan dengan tanggal mundur, hingga tanggal sebelum atau pada waktu dilangsungkannya perkawinan.

Dengan disyaratkannya "pengesahan" oleh Pegawai Pencatat Perkawinan sebagai syarat berlakunya Perjanjian Kawin baik bagi pasangan suami-isteri maupun pihak ketiga, (apabila di kemudian hari telah ada peraturan pelaksanaannya), maka pelanggaran hukum berupa pembuatan perjanjian perkawinan secara di bawah tangan dengan tanggal mundur, dapat dicegah.

\section{PENOLAKAN PEMBUKUAN (PENCATATAN) PERJANJIAN KAWIN}

Sejak berlakunya UUP, banyak terjadi penolakan terhadap permohonan pencatatan/pembukuan Perjanjian Kawin yang hingga setelah dilangsungkannya perkawinan terlambat dicatat/dibukukan, keterlambatan mana kebanyakan disebabkan karena:

(i) Ketidak tahuan bahwa Perjanjian Kawin sejak berlakunya undang undang tersebut tidak lagi dicatatkan / dibukukan / didaftarkan pada Panitera Pengadilan, melainkan pada Pencatatan Sipil; dan

(ii) Sebagai akibat penolakan yang pada masa yang lalu banyak dilakukan oleh Pencatatan Sipil terhadap permohonan pencatatan perkawinan dari Penghayat Kepercayaan, penolakan ma Perjanjian Kawin na berakibat bahwa permohonan pencatatan/pembukuan Perjanjian Kawin yang dibuat oleh Penghayat Kepercayaan juga ditolak oleh Pencatat Sipil;

Menurut Pasal 2 ayat (1) UUP Tentang Perkawinan: "Perkawinan adalah sah apabila dilakukan menurut hukum masing-masing agamanya dan kepercayaannya itu". Adapun Pasal 2 ayat (2) UUP tersebut yang berbunyi: "Tiap-tiap perkawinan dicatat menurut aturan perundang-undangan yang berlaku", menurut Jurisprudensi Mahkamah Agung R.I. hanya bersifat administratif.

Tentang hal ini, Mahkamah Agung R.I. dalam keputusannya tanggal 22 Juli 1991 Reg. No. 2147/Pid/1988 memutuskan bahwa: "Perkawinan yang telah dilangsungkan menurut hukum agamanya dan kepercayaannya adalah sah menurut ketentuan pasal 2 ayat 1 UUP dan masalah tidak dicatatkannya perkawinan yang sudah sah itu sesuai dengan ketentuan pasal 2 ayat (2) UUP, tidaklah menjadikan perkawinan tersebut menjadi tidak sah.

Pendirian Mahkamah Agung ini kemudian dipertegas lagi dengan yurisprudentie Mahkamah Agung tanggal 4 Pebruari 1995 Reg. No.1073K/Pdt/1994. Jadi saat mulai "exist"nya perkawinan bukan saat 
pencatatannya oleh pegawai pencatat perkawinan, melainkan saat dilangsungkannya pemberkatan perkawinannya menurut agama dan kepercayaannya.

Dalam hal fungsionaris agama yang memberkati perkawinan bukan merangkap sebagai pegawai pencatat perkawinan, sehingga pemberkatan perkawinannya terlebih dahulu dilangsungkan oleh fungsionaris agama yang berwenang, baru kemudian dicatat oleh pegawai pencatat perkawinan, dengan demikian pencatatan Perjanjian Kawin pun dilakukan setelah pemberkatan perkawinan yang bersangkutan, dan bukan sebelum atau bersamaan waktunya dengan pemberkatan perkawinan.

Dalam kasus-kasus penolakan pencatatan tersebut diatas, atas permohonan pemohon, Pengadilan selalu menerbitkan Penetapan yang memerintahkan Dinas Kependudukan Dan Pencatatan Sipil (dahulu Catatan Sipil) untuk mencatat/mendaftarkan/membukukan akta-akta Perjanjian Perkawinan yang terlambat dicatat/dibukukan tersebut pada register untuk keperluan tersebut pada Kantor Dinas Kependudukan Dan Pencatatan Sipil (dahulu Catatan Sipil (antara lain Penetapan Pengadilan Negeri Surakarta tertanggal 05 Mei 2011 No. 53/Pdt.P/2011/PN.Ska)).

\section{PENUTUP}

Mengenai beberapa pertanyaan sehubungan dengan perjanjian kawin dikaitkan dengan adanya UUP yang mengatur tentang perkawinan antara lain:

i. Apakah petugas pencatat Catatan sipil melakukan pengesahan atau pencatatan atas perjanjian kawin yang dibuat?

ii. Apakah perjanjian kawin hanya mengatur harta yang berasal dari hibah dan waris saja?

iii. Mengapa perjanjian kawin hanya boleh dibuat sebelum perkawinan sedangkan dalam UUP memungkinkan dibuat perubahan?

Dapat dilihat dari uraian-uraian diatas yang pada intinya:

Apakah petugas pencatat Catatan sipil melakukan pengesahan atau pencatatan atas perjanjian kawin yang dibuat?;

Dari redaksi pasal 29 ayat (1) UUP yang berbunyi : "yang disahkan oleh Pegawai Pencatat Perkawinan", jelas bahwa yang harus dilakukan oleh Pegawai Pencatat Perkawinan terhadap Perjanjian Kawin adalah "pengesahan", apalagi kalau kita kaitkan dengan redaksi ayat (3) UUP yang berbunyi: "Perjanjian Kawin tidak dapat disahkan bilamana melanggar batas-batas hukum, agama dan kesusilaan."

Secara harafiah pengertian hukum dari kata "mencatat" atau "membukukan" dalam arti "overschrijven", seperti yang dimaksud dalam pasal 152 KUHPerdata Indonesia sebagai syarat bagi berlakunya Perjanjian Kawin terhadap pihak ketiga, adalah berbeda maknanya dengan pengertian hukum dari kata "mengesahkan" yang berarti "bewilligen" seperti yang dimuat dalam pasal 36 KUHDagang (Wetboek van Koophandel) Indonesia mengenai pengesahan perseroan terbatas sebagai badan Hukum.

Adapun belum disahkan, dibukukan/didaftarkannya akta Perjanjian Kawin tersebut di atas oleh Pegawai Pencatat Perkawinan hingga saat perkawinan dilangsungkan, tidak mengurangi keabsahan dan berlakunya Perjanjian Kawin tersebut terhadap suami-isteri yang bersangkutan oleh karena pengesahan/pembukuan/pendaftaran Perjanjian Kawin oleh Pegawai Pencatat Perkawinan menurut Pasal 29 ayat (1) UUP hanya disyaratkan bagi berlakunya Perjanjian Kawin tersebut terhadap pihak ketiga 
terkait. menurut Herlien Budiono yang telah disebutkan di atas, makna dari kata "pengesahan" ex. Pasal 29 ayat (1) UUP adalah sama seperti halnya dengan makna pasal 52 KUHPerdata.

Terlepas dari perbedaan pengertian hukum antara istilah hukum "pembukuan (pencatatan) dalam arti "overschrijving", dan "pengesahan" dalam arti "bewilliging" tersebut diatas, pendapat Herlien Budiono tersebut dapat kita pahami karena memang pada kenyataannya yang dilakukan oleh Pegawai Pencatat Perkawinan hingga saat ini bukanlah mengesahkan melainkan hanya membukukan (mencatat) Perjanjian Kawin, karena kata "disahkan" ex pasal 29 ayat (1) UUP hingga kini belum ada peraturan pelaksanaannya.Pengesahan ex. pasal 29 ayat (1) UUP belum berlaku karena semua peraturan perundang-undangan yang terbit setelah UUP hanya mengatur mengenai "pencatatan" dan bukan "pengesahan", sehingga syarat "pengesahan" ex pasal 29 ayat (1) UUP belum berlaku karena belum ada peraturan pelaksanaannya.

Meskipun UUP dalam Pasal 29 ayat (1) dan (2) menyebutkan mengenai "pengesahan" Perjanjian Kawin , namun "pengesahan" ex. pasal 29 ayat (1) dan (2) UUP, harus dianggap belum berlaku, karena belum ada peraturan pelaksanaannya, mengingat UU, Peraturan Presiden, dan Peraturan Daerah yang ada hingga saat ini semuanya mengatur bahwa Pencatatan Sipil bukan mengesahkan melainkan mencatat/membukukan Perjanjian Kawin, sehingga apa yang hingga kini dilakukan Catatan Sipil berkenaan dengan Perjanjian Kawin adalah hanya mencatat (membukukan) dan bukan mengesahkan.

Apabila kita teliti ketentuan pasal 1 angka 17 undang-undang No. 23 Tahun 2006 dan Pasal 1 angka16 Peraturan Presiden Republik Indonesia No. 25 Tahun 2008 yang keduanya berbunyi:
"Peristiwa penting adalah kejadian yang dialami oleh seseorang meliputi kelahiran, kematian, lahir mati, perkawinan, perceraian, pengakuan anak, pengesahan anak, pengangkatan anak, perubahan nama dan perubahan status kewarganegaraan“, maka nampak jelas bahwa dalam peristiwa penting yang dialami seseorang yang dicatat oleh Catatan Sipil tidak disebutkan secara eksplisit mengenai Perjanjian Kawin.

\section{PENDAPAT BAHWA PERJANJIAN KAWIN HANYA MUNGKIN DIADAKAN MENGENAI HARTA YANG DIMAKSUDKAN DALAM PASAL 35 AYAT 2 UU No.1 TAHUN 1974 `}

Pendapat ini didasarkan pada redaksi: "sepanjang para pihak tidak menentukan lain" pada akhir pasal 35 ayat (2) UUP.

Redaksi tersebut oleh sementara pihak ditafsirkan seakan-akan Perjanjian Kawin hanya boleh dibuat mengenai harta yang disebutkan dalam pasal 35 ayat 2 UUP, yaitu harta bawaan dan harta yang berasal dari hibah atau warisan.

\section{PENDAPAT PAKAR HUKUM}

R. Subekti, Guru Besar Hukum Perdata dan Mantan Ketua Mahkamah Agung R.I., menulis sebagai berikut: "Baik KUHPerdata maupun Undang-undang Perkawinan mengenal apa yang dinamakan perjanjian perkawinan Itu adalah suatu perjanjian mengenai harta benda suami-isteri selama perkawinan mereka, yang menyimpang dari asas atau pola yang ditetapkan dalam perjanjian kawinan oleh undang-undang".

Demikian pula Mr. Ko Tjay Sing menyebutkan: "Ketentuan ketentuan undangundang mengenai harta kekayaan suami dan

\footnotetext{
9 R.Subekti, Ringkasan Tentang Hukum Keluarga Dan Hukum Waris, Jakarta: Intermasa, 1990, hlm. 8-9 .
} 
isteri yang dimaksudkan di atas untuk sebagian tidak merupakan hukum memaksa. Suami dan isteri boleh menyimpang dari ketentuan ketentuan tersebut ${ }^{10}$ (lihatlah pasal 105 ayat (3), 119 ayat (1), 124 ayat (2) jo. 140 ayat (3) KUHPerdata).

Juga dalam redaksi Pasal 139 KUHPerdata disebutkan: "Dengan mengadakan Perjanjian Kawin, kedua calon suami-isteri adalah berhak menyiaperjanjian kawinan beberapa penyimpangan dari peraturan undang-undang sekitar persatuan harta kekayaan, asal perjanjian itu tidak menyalahi tata susila yang baik atau tata tertib umum..."

\section{$\begin{array}{lllll}\text { PASAL } & 35 & \text { (1) UUP } & \text { BUKAN }\end{array}$ MERUPAKAN DWINGEND RECHT (PERATURAN YANG BERSIFAT MEMAKSA) SEHINGGA BOLEH DISIMPANGI DENGAN PERJANJIAN KAWIN}

Tentu saja penyimpangan dalam Perjanjian Kawin hanya dimungkinkan terhadap ketentuan yang bersifat mengatur dan bukan terhadap ketentuan yang bersifat memaksa.

Apabila kita lihat pasal 35 ayat (1) UUP, disana tidak kita jumpai redaksi yang menyatakan bahwa ketentuan tersebut merupakan ketentuan yang bersifat memaksa (dwingend), sehingga boleh saja dikesampingkan dengan Perjanjian Kawin.

Hal tersebut juga ternyata dari redaksi pasal 47 ayat (2) Kompilasi Hukum Islam yang berbunyi sebagai berikut:

"(2) Perjanjian tersebut dalam dalam ayat (1) dapat meliputi percampuran harta pribadi dan pemisahan harta pencaharian masing masing sepanjang hal itu tidak bertentangan dengan hukum Islam”.

\footnotetext{
${ }^{10}$ Supra Note 5, hlm. 238.
}

Sebagai perbandingan dapat kita lihat ketentuan pasal 139 KUH Perdata yang mengatur bahwa dengan Perjanjian Kawin, kedua calon suami isteri adalah berhak menyiaperjanjian kawinan beberapa penyimpangan dari peraturan undangundang sekitar persatuan harta kekayaan.

Dari bunyi pasal 139 KUHPerdata tersebut nampak jelas bahwa pembuat undang- undang berpendapat bahwa peraturan undang-undang mengenai persatuan harta kekayaan i.c. pasal 119 KUHPerdata bukan merupakan peraturan undang-undang yang bersifat memaksa ( $d$ wingend recht) melainkan bersifat mengatur, sehingga dapat disimpangi dengan dengan Perjanjian Kawin.

KEHARUSAN MEMBUAT PERJANJIAN KAWIN SEBELUM ATAU PADA SAAT PERKAWINAN SERTA PERUBAHAN PERJANJIAN KAWIN SELAMA PERKAWINAN BERLANGSUNG

Menurut Pasal 149 KUHPerdata : “ Setelah perkawinan berlangsung, perjanjian perkawinan dengan cara bagaimanapun, tak boleh diubah ", Pasal 29 ayat (1) UUP mengharuskan Perjanjian Kawin dibuat sebelum atau pada saat perkawinan dilangsungkan atau dengan perkataan lain suatu Perjanjian Kawin tidak boleh dibuat sepanjang perkawinan.

Keharusan membuat Perjanjian Kawin sebelum atau pada waktu perkawinan disebabkan karena pembuat undang-undang menganut azas bahwa status hukum harta benda perkawinan selama perkawinan tidak boleh berubah. Tentang hal ini Ko Tjay menguraikan bahwa pembuat undang undang menghendaki agar sejak dilangsungkannya perkawinan diketahui pasti apakah telah dibuat Perjanjian Kawin dan isinya. ${ }^{11}$ Demikian pula pembuat undang-undang

11 Ibid, hlm. 243. 
tidak menghendaki bahwa setelah dilangsungkannya perkawinan diadakan perubahan terhadap Perjanjian Kawin yang berakibat timbulnya ketidakpastian hukum bagi pihak ketiga yang mengadakan hubungan hukum dengan suami dan/isteri yang bersangkutan.

Di Belanda prinsip/azas tentang tidak dapat diubahnya Perjanjian Kawin setelah dilangsungkannya perkawinan telah dilepaskan. Menurut Undang-Undang tahun 1956, Perjanjian Kawin boleh dibuat atau diubah setelah perkawinan berlangsung, asalkan perkawinan telah berlangsung sekurang-kurangnya 3 tahun dan dengan izin Pengadilan (Pasal 203 dan 204)yang kemudian diubah menjadi sekurangkurangnya 1 tahun. Juga dikhawatirkan, bahwa karena pengaruh suami, isteri akan menyetujui perubahan terhadap Perjanjian Kawin yang sebenarnya tidak dikehendaki oleh isteri. $^{12}$

Tentang hal tersebut Mr. E.A.A Luijten menguraikan bahwa menurut Pasal 114 ayat (1) Nieuw Burgerlijk Wetboek diatur bahwa Perjanjian Kawin dapat dibuat baik oleh calon suami isteri sebelum perkawinan maupun oleh suami isteri sepanjang perkawinan. ${ }^{13}$ Azas tidak boleh berubahnya status hukum harta benda perkawinan sepanjang perkawinan sekarang telah hilang sama sekali (telah ditinggalkan sama sekali). Dalam masyarakat modern orang berpendapat tidak lagi ada alasan untuk mempertahankan (memegang teguh) azas tersebut yang sebagian besar ditopang oleh kecemasan pembuat undangundang mengenai posisi wanita (isteri) terhadap kewenangan suami yang berlebihan yang dapat merugikan istri.

12 Ibid.

${ }^{13}$ Mr. E.A.A Luijten, Het Personen En Familierecht in het Nieuwe Burgerlijk Wetboek, Tjeenk WillinkZwolle, 1970, hlm. 97.
Pada pasal 118 Buku 1 BW Belanda memungkinkan pembuatan atau perubahan suatu Perjanjian Kawin setelah suatu perkawinan dilangsungkan, asalkan perkawinan tersebut telah berlangsung sekurang-kurangnya satu tahun dan untuk pembuatan atau perubahan Perjanjian Kawin sepanjang perkawinan tersebut diperlukan izin (persetujuan) Pengadilan (pasal 119 ayat (1) Buku 1 BW Belanda). Hakim berwenang untuk menolak untuk memberikan izin (persetujuan) tersebut apabila pembuatan atau perubahan tersebut tidak mempunyai alas an yang berdasar atau terdapat bahaya bahwa pembuatan atau perubahan Perjanjian Kawin tersebut akan merugikan pihak ketiga.

Selanjutnya dalam ayat (4) dari pasal 119 Buku 1 BW Belanda tersebut disebutkan bahwa apabila akta Perjanjian Kawin atau perubahannya tersebut tidak dibuat dalam waktu tiga bulan sejak penetapan pengadilan yang memuat pemberian izin (persetujuan) itu mempunyai kekuatan hukum yang pasti untuk dilaksanakan, maka izin (persetujuan) tersebut gugur.

Pasal 29 ayat (4) UUP mengatur bahwa selama perkawinan berlangsung Perjanjian Kawin tidak dapat diubah, kecuali bila dari kedua belah pihak ada perjanjian untuk mengubah dan perubahan tidak merugikan pihak ketiga. Dengan dimungkinkannya perubahan Perjanjian Kawin selama perkawinan menurut pasal 29 ayat (4) UUP, maka sebetulnya keharusan untuk membuat atau merubah Perjanjian Kawin sebelum atau pada saat perkawinan, menjadi tidak berdasar lagi. Mengenai ketentuan pasal 29 ayat (4) UUP tersebut ada yang berpendapat bahwa mengingat adanya persyaratan bahwa perubahan tersebut tidak boleh merugikan pihak ketiga, maka praktis perubahan Perjanjian Kawin sepanjang perkawinan tersebut tidak mungkin dilakukan karena apakah perubahan tersebut akan merugikan 
pihak ketiga atau tidak, hal tersebut belum dapat diketahui pada waktu perubahan tersebut dibuat.

Penafsiran sedemikian jelas bertentangan dengan redaksi Pasal 29 ayat (4) UUP yang secara tegas memperkenankan perubahan Perjanjian Kawin sepanjang perkawinan.Pendapat lain mengatakan bahwa perubahan Perjanjian Kawin sepanjang perkawinan secara tegas dimungkinkan menurut pasal 29 ayat (4) UU No. 1 Tahun 1974, adapun untuk memenuhi persyaratan bahwa perubahan tersebut tidak boleh merugikan pihak ketiga, cukup dalam perubahan Perjanjian Kawin tersebut dimuat suatu clausula yang mengatur bahwa perubahan tersebut tidak berlaku terhadap pihak ketiga, sepanjang pihak ketiga yang bersangkutan dirugikan oleh perubahan Perjanjian Kawin tersebut. Ini berarti bahwa perubahan Perjanjian Kawin tersebut tetap berlaku bagi pihak ketiga yang tidak dirugikan oleh perubahan tersebut.

Dengan demikian ketiga permasalahan tersebut harus dijelaskan agar tidak merusak semua peraturan hukum dengan adanya penafsiran dan pelaksanaan yang berbeda.

\section{DAFTAR PUSTAKA}

\section{Buku-buku:}

\section{E.A.A Luijten, Het Personen En Familierecht in het Nieuwe Burgerlijk Wetboek, Tjeenk Willink-Zwolle, 1970 .}

\section{Happy Susanto, Pembagian Harta Gono Gini Saat Terjadinya Perceraian, Jakarta: Visimedia, 2008.}

Herlien Budiono, "Kumpulan Tulisan Hukum Perdata di Bidang Kenotariatan, Buku Kedua, Bandung: Citra Aditya Bakti, 2010.
Ko Tjay Sing, Hukum Perdata Jilid I, Hukum Keluarga (Diktat Lengkap), Semarang: Etikad Baik, 1981.

R.Subekti, Ringkasan Tentang Hukum Keluarga Dan Hukum Waris, Jakarta: Intermasa, 1990.

R. Soetojo Prawirohamidjojo dan Asis Safioedin, "Hukum Orang Dan Keluarga", cetakan kelima, Bandung: Alumni, 1986. 